\title{
Comparative Diagnostics of the Development of the Service Sector of the Russian Federation, Siberian Federal District and Krasnoyarsk Territory
}

\author{
Grass Tatyana Petrovna \\ Federal State Budgetary Educational Institution of Higher \\ Education \\ St. Petersburg State University of civil aviation\&quot \\ Sankt-Peterburg, Russia \\ tpgrass@mail.ru
}

Esina Anna Sergeevna

Trade and economic Institute

Federal State Autonomous Educational Institution of Higher Education

"Siberian Federal University"

Krasnoyarsk, Russia

yesinaanna28@gmail.com

Tereshchenko Natalia Nikolaevna

Trade and economic Institute

Federal State Autonomous Educational Institution of Higher Education

"Siberian Federal University"

Krasnoyarsk, Russia

tereshchenko.65@mail.ru

\author{
Esina Olga Nikolaevna \\ Trade and economic Institute \\ Federal State AutonomousEducational Institution of Higher \\ Education \\ "Siberian FederalUniversity" \\ Krasnoyarsk, Russia \\ emel-olga@mail.ru
}

Kazantseva Elena Evgenevna

Trade and economic Institute

Federal State Autonomous Educational Institution of Higher Education

"Siberian Federal University"

Krasnoyarsk, Russia

kazantseva1508@gmail.com

Trusova Svetlana Vasilevna

Federal state educational institution of higher education

"Khakass state University named after N. F. Katanov"

Abakan, Russia

sertrus@mail.ru

\begin{abstract}
Based on the study and generalization of the works of foreign and domestic scientists, as well as their own research, the authors propose an author's method for comparative diagnostics of the main indicators of the development of the service sector and the factors that determine them and tested it on the materials of the Russian Federation, Siberian Federal District and Krasnoyarsk Territory.

Based on the studies, the main STEP factors that influence the development of the service sector were selected and a correlation and regression analysis was performed to characterize the relationship between the volume of the service sector and the main determining factors. As a result of the studies, economic and mathematical models for the development of the volume of the services sector as a whole were built, including a number of its main industries, which allows us to determine the prospects for the development of the services sector and the investment attractiveness of the regions.
\end{abstract}

Keywords: comparative diagnostics technique, service sector, STEP factors, development indicators, correlation and regression analysis, economic and mathematical models

\section{INTRODUCTION}

The service sector is one of the most dynamically developing sectors of the Russian economy having a significant impact both on the functioning of individual industries and on the development of the economic system as a whole.

At the same time, the successful implementation of the goals of sustainable development of the economy and individual market entities is largely determined by the efficiency of the services sectors and improved access to specific services (Fiorini, M., Hoekman, B. [8]. 
In this regard, the study of various aspects of the development of the service sector is becoming increasingly important and practical importance for all market entities.

One of the effective methods of economic research in modern conditions is economic diagnostics, which allows retrospective and promising studies based on a system, differentiated, integrated approaches.

\section{LITERATURE REVIEW AND RESEARCH METHODS}

A wide range of foreign and Russian economists (Dalevska N., Khobta V., Kwilinski A., Kravchenko S. [1], Razumova E., Ilienko O. [16]; Ihnatiuk V. [12], Dmitrieva M., Strekaleva T., Suslov D., Tereshchenko N. [6], Demchenko S. [5], Zhironkin S. [20] and others).

However, the issues of diagnostics (including comparative), indicators of the development of the service sector and factors determining it based on the synthesis of a retrospective and perspective analysis using economic and mathematical modeling of economic processes are still not fully and deeply studied, which necessitates further research.

To obtain scientifically based research results, we used both general scientific research methods, such as analysis and synthesis methods, abstractions, comparisons, and generalizations, and others, as well as special methods of economic diagnostics, which allow one to obtain multivariate diagnostic analysis in conditions of incomplete information and a high degree of uncertainty.

Economic diagnostics is a research process aimed at determining the state of an object, subject, phenomenon or process by implementing a set of research procedures and applying various methods and identifying weak, vulnerable aspects of activity in order to establish a result in the form of a diagnosis of the object of study [8].

Economic diagnostics is based on the synthesis of a retrospective and perspective study of the dynamic series of development indicators of the service sector and the factors that determine it, with the widespread use of statistical and economic-mathematical methods.

Based on the scientific developments of a number of scientists in the field of methods and tools for economic and mathematical modeling (Dalevska N., Khobta, V., Kwilinski A., Kravchenko S. [1], Razumova E., Ilienko O. [16], Ihnatiuk V. [12], Dmitrieva D., Strekaleva T., Suslov D., Tereshchenko N. [6] and others) a technique is proposed for developing economic and mathematical models for the development of individual services industries depending on the main factors that determine them.

The study, generalization and critical analysis of the works of foreign (Dalevska, N., Khobta, V.) and Russian scientists (Kwilinski, A., Kravchenko, S.) [1], as well as the authors 'own studies [8], allowed us to propose an author's methodology comparative diagnostics of the main indicators of the development of the service sector and the factors that determine them (Figure 1). This technique includes a research flowchart and is a basic component of comparative diagnostics, which allows carrying out research on the basis of multi-parameter, target, systemic, dynamic, differentiated approaches.

\section{RESULTS}

In the framework of retrospective diagnostics, according to our methodology, we initially diagnose the main indicators of the development of the service sector in the context of three regions - the Russian Federation (RF), the Siberian Federal District (SFD) and the Krasnoyarsk Territory.

An analysis of the change in the share of the service sector in the Russian Federation, Siberian Federal District and the Krasnoyarsk Territory in the grossdomestic product (Figure 2) showed that, despite the constant growth in the volume of the service sector, its share has multidirectional dynamics.

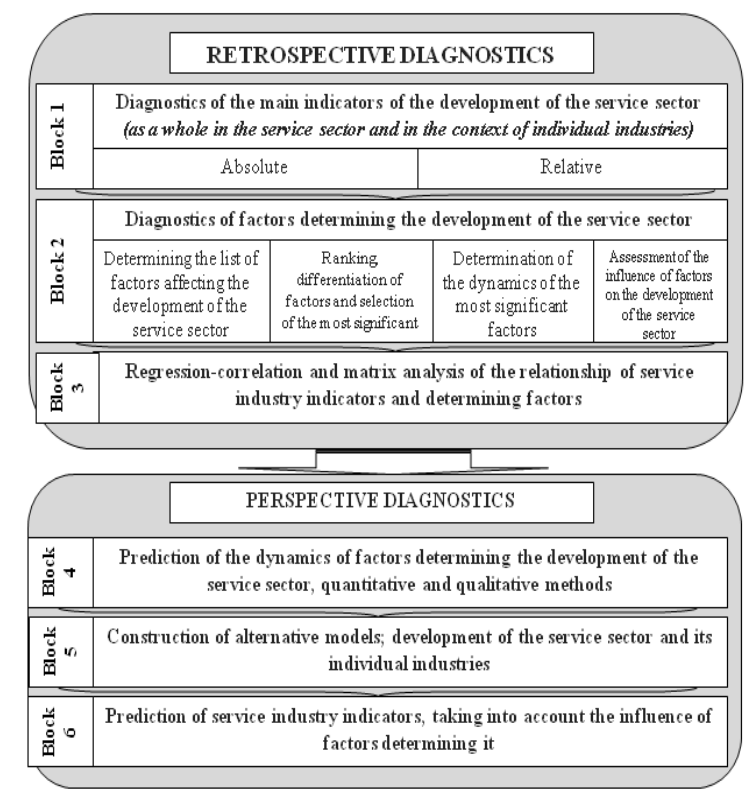

Fig. 1. Block diagram of the comparative diagnostics of the development of the service sector

In relation to the Russian Federation, an increase in the share of all services in the GDP structure is observed, in 2010 the share of the services sector was $58.7 \%$, and in 2017 $62.0 \%$.

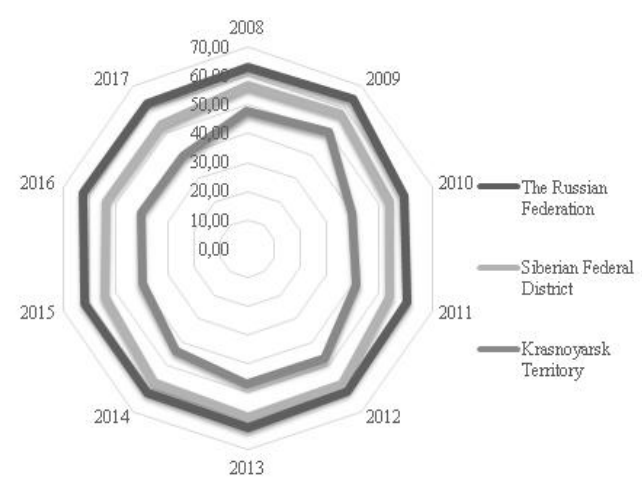

Fig. 2. The share of services in the gross domestic product in the Russian Federation, Siberian Federal District and Krasnoyarsk Territory, \% 
Since 2008, the share of the services sector has been growing in the Siberian Federal District since 2008, and in 2013 it reaches its maximum value for the given period $(58.4 \%)$; however, since 2014 , the share of the services sector in the district's GRP has been steadily decreasing. In the Krasnoyarsk Territory, the share of the service sector was also unstable. From 2010 to 2012, there is an increase in the share of the service sector in GRP (from $40 \%$ to $47.6 \%$ ), however, starting from 2013, this indicator decreases, which in 2016 reaches $40.5 \%$.

Studies have shown that between 2008 and 2017, the ratio of growth rates of the services sector as a whole in Russia was negative (Figure 3). In the Siberian Federal District and Krasnoyarsk Territory, there is also a decrease in the rate of change in the volume of services in the analyzed period. However, in 2014 and 2015, a slight increase in growth rates was observed within the dynamic range of this indicator.

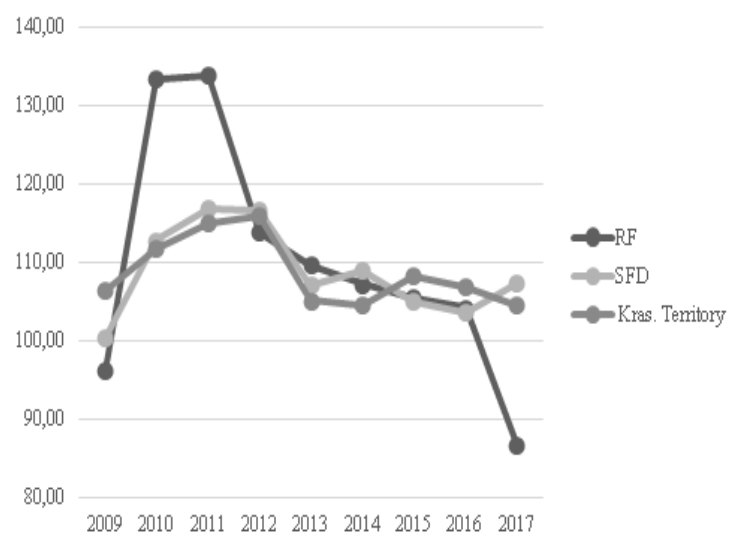

Fig. 3. Dynamics of growth rates in the scope of services in the Russian Federation, Siberian Federal District and Krasnoyarsk Territory (chain method), \%

In the analyzed period, there has been an increase in the volume of the services sector per 1000 inhabitants both in the Russian Federation, and in the Siberian Federal District and the Krasnoyarsk Territory (Figure 4). This dynamics should be evaluated positively, since with an increase in the volume of the service sector, the quality of life of the population of the country and regions is increasing.

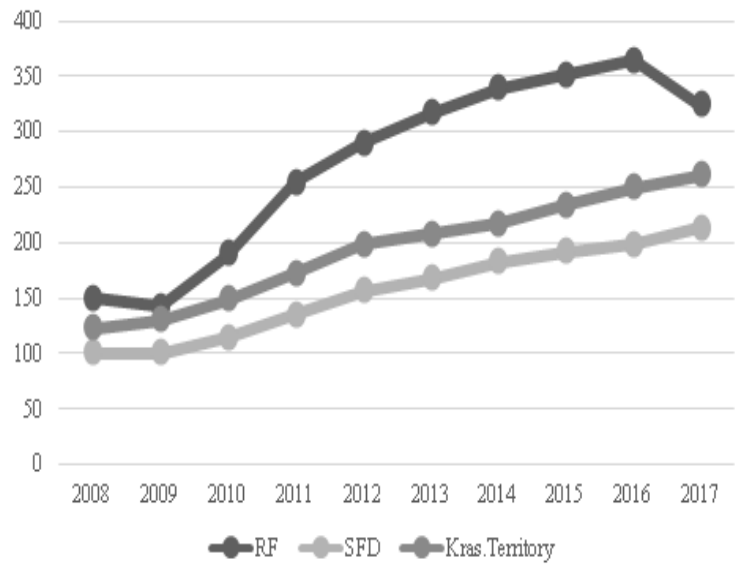

Fig. 4. Dynamics of the volume of the services sector per 1000 inhabitants billion rubles

Summarizing the foregoing, it can be noted that the development of the service sector in the analyzed regions is quite dynamic and stable, which is explained by an increase in the industrialization of society and at the same time helps to improve the quality of life of the population.

At the second stage of the methodology presented by us (Figure 2), diagnostics of factors determining the development of the service sector is offered. In identifying the tightness of communication and the degree of influence of individual factors on the service sector, the following quantitative factors were selected:

- socio - demographic: population (X1); natural population growth (X2); unemployment rate (X3); cost of living (X4);

- technological: the number of organizations performing research (X5); innovative activity of organizations (X6); volume of innovative goods, works and services $(\mathrm{X} 7)$;

- economic: inflation rate (X8); refinancing rate (X9); average per capita incomes of the population (X10); the population having incomes below the subsistence level (X11).

Diagnostics of the factors determining the development of the Russian services sector showed that for all indicators that affect the volume of the services sector, positive dynamics can be traced.

A positive point is the increase in the living wage and per capita income, which may reflect an improvement in the quality of life of the population. The negative point is the increase in the share of the population with cash incomes below the subsistence level.

The group of socio-demographic factors shows an increase in population and a decrease in unemployment, which should be evaluated positively

Technological factors are also growing, which reflects an increase in the scientific and innovative potential of our country. An exception can be considered 2017, in which there is a decrease in all indicators. This change may be due to the 
TABLE I. CORRELATION MATRIX

funding of scientific sectors.

Diagnosis of factors affecting the service sector in the Siberian Federal District showed that there is an increase in the total population of the Siberian Federal District and an increase in natural growth; there is multidirectional dynamics of the unemployment rate, in recent years a decrease has been recorded, although the level is much higher than in the whole country; there is an increase in the cost of living, this change should be evaluated positively. the inflation rate and refinancing rate have been declining in recent years, and per capita incomes of the population are growing.

Considering the results of the diagnosis of factors that determine the development of the service sector in the Krasnoyarsk Territory, it can be noted that there is an increase in the total population of the Krasnoyarsk Territory and an increase in natural growth, there are multidirectional dynamics of the unemployment rate, and in recent years a decrease has been recorded, although the level is much higher than in general by country and district; growth of the living wage and per capita incomes of the population.

In accordance with the flowchart (Figure 1), to determine the significance and highlight the most important factors, we calculate the correlation between the effective indicator and all factors that influence. To calculate the correlation, we use the "Data Analysis" function in MSExcel.

Having calculated the correlation, it was revealed that the greatest of the selected factors affect the volume of the service sector:

- the volume of innovative goods, works and services (0.991);

- average per capita income (0.986);

- cost of living (0.956).

The least impact is exerted by the population with incomes below the subsistence level $(0.04)$, the refinancing rate $(0.143)$ and the inflation rate (0.403). When constructing an economic-mathematical model, factors are involved in the analysis whose correlation coefficient is greater than 0.7 . Accordingly, other factors can be excluded from the model. To establish the relationship between the effective indicator and factors, as well as the relationship of factors among themselves, we will build a correlation matrix (table I).

\begin{tabular}{|c|c|c|c|c|c|c|c|c|c|c|c|c|}
\hline & $Y$ & Xl & $X 2$ & X3 & X4 & XS & 86 & X7 & 188 & XO & \begin{tabular}{|l|}
$X 10$ \\
\end{tabular} & XII \\
\hline$Y$ & 1,000 & & & & & & & & & & & \\
\hline $\mathrm{XI}$ & 0,733 & 1,000 & & & & & & & & & & \\
\hline $\mathrm{X} 2$ & 0,903 & \begin{tabular}{|c|}
0,436 \\
\end{tabular} & 1,000 & & & & & & & & & \\
\hline $\mathrm{X} 3$ & $\cdot 0,821$ & $.0,446^{\circ}$ & $\cdot 0,665$ & 1,000 & & & & & & & & \\
\hline Xt & 0,910 & 0,934 & 0,694 & $\cdot 0,687$ & 1,000 & & & & & & & \\
\hline Xi & 0,660 & 0,916 & 0,400 & 0,486 & 0,820 & 1,000 & & & & & & \\
\hline \begin{tabular}{|l|}
$\mathrm{X} 6$ \\
\end{tabular} & 0,264 & $.0,792$ & 0,068 & 0,098 . & 0,586 & 0,638 & 1,000 & & & & & \\
\hline $\mathrm{X} 7$ & 0,979 & 0,798 & 0,830 & $\cdot 0,445$ & \begin{tabular}{|c|}
0,940 \\
\end{tabular} & $0,682$. & $\cdot 0,379$ & 1,000 & & & & \\
\hline X8 & 0,278 & 0,288 & 0,217 & $0,166^{\circ}$ & 0,350 & $\cdot 0,049$ & 0,247 & 0,370 & 1,000 & & & \\
\hline $\mathrm{XO}$ & $\cdot 0,996$ & 0,094 & 0,292 & 0,159 & $\cdot 0,088$ & 0,266 & $.0,238 \cdot$ & $\cdot 0,073$ & 0,607 & 1,000 & & \\
\hline $\mathrm{X} 10$ & 0,959 & 0,856 & 0,798 . & $.0,752$ & 0,0981 & 0,722 & $\cdot 0,461$ & 0,977 & 0,357 & $\cdot 0,153$ & 1,000 & \\
\hline XII & $\cdot 0,046$ & $0,584$. & 0,364 & 0,167 & 0,295 & $0,67 t$ & 0,754 & 0,015 & 0,067 & 0,403 & 0,108 & 1,000 \\
\hline
\end{tabular}

Having identified significant factors, we will conduct a regression analysis and build an economic and mathematical model for the development of the service sector (table II). For clarity, the application of the proposed methodology industry services have been selected having the largest revenue, both in general and per capita.

TABLE II. ECONOMIC AND MATHEMATICAL MODELS FOR THE DEVELOPMENT OF THE SERVICES SECTOR AND ITS INDIVIDUAL INDUSTRIES

\begin{tabular}{|c|c|}
\hline \multicolumn{2}{|r|}{ The Russian Federation } \\
\hline Servicessector & $y=320264,4-1865,2 \times 1+41.8 \times 2-2275,7 \times 3+9,9844-3,5 \times 5+0,003 \times 7-2,6 \times 10$ \\
\hline Construction & $y=5881,6+4,4 \times 2-343 \times 3+0,3 \times 4-3,1 \times 5+0,0001 X 7-0,08 \times 10$ \\
\hline $\begin{array}{l}\text { Wholesale and retail trade; repair of } \\
\text { motor vehicles, motorcycles, } \\
\text { household products and personal } \\
\text { items }\end{array}$ & $y=58256,6-294,8 \times 1+42,2 x 2-1322,7 \times 3+1,7 x 4-1,3 \times 5-0,00177-0,06 \times 10$ \\
\hline Transport and comm unications & $y=-88736,1+765,6 \times 1-428,4 \times 3+0,9 \times 4-4,5 \times 5-0,00002 \times 7-0,17 \times 10$ \\
\hline $\begin{array}{c}\text { Real estate operations, rental and } \\
\text { provision of services }\end{array}$ & $y=1181,5+117,4 \times 1+15,32-813 \times 3+1,9 \times 4+0,1 \times 5+0,0001 X 7-0,64 \times 10$ \\
\hline \multicolumn{2}{|r|}{ The Siherian Federal District } \\
\hline Servicessector & $y=3645,3+158,5 \times 2-126,9 \times 3+0,4 \times 4-0,5 \times 5-0,0001 \times 7-0,1 \times 10$ \\
\hline Construction & $y=658,3+65,6 \times 2-45,5 \times 3+0,07 \times 4-0,5 \times 5-0,00002 \times 7-0,03 \times 10$ \\
\hline $\begin{array}{l}\text { Wholesale and retail trade; repair of } \\
\text { motor vehicles, motorcycles, } \\
\text { household products and personal } \\
\text { items }\end{array}$ & $y=566,7+8,7 \times 2-31,6 \times 3+0,05 \times 4-0,03 \times 5+0,00001 \times 7+6,3 \times 10$ \\
\hline Transport and com m unications & $y=1182,6-18,03 \times 2+0,13 X 4-0,02 \times 5+0,0001 X 7-0,05 X 10$ \\
\hline $\begin{array}{l}\text { Real estate operations, rental and } \\
\text { provision of services }\end{array}$ & $y=135,1-18,5 \times 2+0,07 \times 4-0,1 \times 5+0,00008 X 7-0,003 \times 10$ \\
\hline \multicolumn{2}{|r|}{ Krasto yarskterritory } \\
\hline Servicessector & $y=371-3,2 X 2+0,04 X 4-0,08 X 5+0,00005 X 7+0,002 \times 10$ \\
\hline Construction & $y=146,1+12,4 \times 2+0,02 \times 4+0,007 \times 5+0,00002 \times 7-0,01 \times 10$ \\
\hline $\begin{array}{l}\text { Wholesale and retail trade; repair of } \\
\text { motor vehicles, motorcycles, } \\
\text { household products and personal } \\
\text { items }\end{array}$ & $y=81,8+5,2 \times 2+0,0006 \times 4+0,00002 X 7-0,02 \times 10$ \\
\hline Transport and com munications & $y=24,4-19,1 \times 2+0,004 \times 4-0,03 \times 5-9,6 \times 7+0,01 \times 10$ \\
\hline $\begin{array}{l}\text { Realestate operations, rental and } \\
\text { provision of services }\end{array}$ & $y=-26,1-6,2 X 2+0,004 X 4-0,01 X 5-2,1 X 7+0,007 X 10$ \\
\hline
\end{tabular}

Based on the obtained models, it is advisable to forecast the studied indicators for the future, taking into account the 
International Journal of Civil Engineering and Technology. - 2019 .-- 10 (2), pp. 1877-1884 https://www.scopus.com/inward/record.uri?eid=2-s2.085066228496\&partnerID=40\&md5=c53c3928c59824804ea81214c1089 $\mathrm{dc} 8$

To organize similar studies, a number of Russian scientists (Kitova O., Savinova V., Dyakonova L., Bruskin S., Beshmelnitskiy A., Danko T., Sekerin V.) suggest the creation of situational centers, capable of assessing socio-economic indicators at the federal and regional levels in real time, conduct a planned and factual analysis and predict the development of the service sector for the future using various quantitative and qualitative methods [12].

On the scale of the Krasnoyarsk Territory, we propose assigning these research functions to the Research Center for Monitoring the Consumer Market and Services of the Siberian Federal University, which is capable of carrying out research in various sectors of the service sector on orders from both state and executive authorities and interested individual market entities.

\section{CONCLUSION}

Thus, the comparative diagnostics performed allows us to evaluate the development of the services sector and its individual industries, as well as the factors determining them, in retrospect and perspective. Using the presented analysis results and obtained forecasts of the development of the service sector allows market entities to objectively assess the prospects for their development and the effectiveness of their functioning in this sector of the economy, which will increase the competitiveness of the market and the effectiveness of activities taking into account environmental factors.

\section{REFERENCES}

[1] A model for estimating social and economic indicators of sustainable development / Dalevska N., Khobta V., Kwilinski A., Kravchenko S. // Entrepreneurship and Sustainability Issues Volume 6, Issue 4, June 2019, p. 1839-1860

[2] Abdikeev N., Bogachev Y., Melnichuk M. Identifying the factors that contribute to sustainable development of the national economy // European Research Studies Journal Volume 21, Issue 2, 2018, p. 411425

[3] Alexander W.R.J., Pei Z. Factors affecting trade in services: evidence from panel data / Applied Economics Volume 51, Issue 34, 21 July 2019, p. 3730-3739

[4] C.I.A. theWorldFactbook [Electronic resource]: official site. Access Mode: https://www.cia.gov/library/publications/the-world-factbook/.

[5] Demchenko S.K., Zlotnikov M.S., Melnikova T.A., Demchenko O.S. Theoretical and methodological bases of improving the assessment of the effectiveness and synchronous functioning of a country socioeconomic system under conditions of transformation //
[6] Dmitrieva M.The capacity of the market of educational services in Krasnoyarsk territory in the field of higher education / Marina Dmitrieva, Tatyana Strekaleva, Dmitriy Suslov, Natalia Tereshchenko // Proceedings The 32nd IBIMA conference (November 15-16, 2018, Seville, Spain) - p. 3485-3494. ISBN: 978-0-9998551-1-9 (indexing at Web of Science and SCOPUS)

[7] Donets L., Davydiuk, Diagnostics of the external factors influence on the tourism enterprises strategic planning // Economic Annals-XXI Volume 3-4, 2014, p 43-46

[8] Esina O., Salova A., Tereshchenko N. Economic diagnostics of the organization of the service sector: monograph. - Moscow. Publishing House "LLC Envelope", 2018. - 196 p.

[9] Federal customs service [Electronic resource]: official website. Mode of access: www.customs.ru

[10] Federal State Statistics Service [Electronic resource]: official site. Access mode: www.gks.ru.

[11] Fiorini, M., Hoekman, B. Services trade policy and sustainable development // World Development Volume 112, December 2018, p. 112

[12] Information-analytical system for forecasting indicators of the social and economic sphere of the Russian Federation / Kitova, O., Savinova, V., Dyakonova, L., Bruskin, S., at.al // European Research Studies Journal Volume 20 , Issue 4, 2017, p. 275-283

[13] Krasnoyarsk Territory in numbers 2018 [Electronic resource]: official site. Access Mode: https://krasstat.gks.ru/.

[14] Melnyk O., Todoshchuk A., Adamiv M. The role of socio-economic diagnostics in an enterprise management system// Baltic journal of economic studies Volume 4, Issue 3, 2018, p. 165-171

[15] Plotnikov V., Volkova A., Nikitin Y., Plotnikov A. Methodical Aspects of Designing and Implementing Company Development Strategies: the Case of Services Sector Organizations Innovation management and education excellence through vision 2020, VOLS IV -VI , 2018, p. 2510-2515

[16] Razumova E., Ilienko O., Ihnatiuk V. Implementation of the economic and mathematical model for the development of the complex of services for passengers in the railway sector// Baltic journal of economic studies Volume 4, Issue 2, 2018, p. 191-197

[17] Russian statistical yearbook. 2017: Stat. collection / Rosstat. - Moscow., 2017 - $686 \mathrm{~s}$.

[18] Unified interdepartmental information and statistical system [Electronic resource]: official site. Access mode: www.fedstat.ru.

[19] Zakshevskii V., Merenkova I., Novikova, I. , Kusmagambetova, E. Methodological Toolkit for Diagnosing the Diversification of Rural Economy// Ekonomika regiona-economy of region Volume 15, Issue 2, 2019, p. 520-533

[20] Zhironkin S., Demchenko, S., Kayachev, G., Taran, E., Zhironkina, O. Convergent and nature-like technologies as the basis for sustainable development in the 21st Century // E3S Web of Conferences, 2019. - Volume $\quad 105, \quad$ P.1-6. www.e3sconferences.org/articles/e3sconf/abs/2019/31/e3sc onf_iims18_03008/e3sconf_iims18_03008.html 